\title{
PENGARUH INCOME SMOOTHING, GOOD COORPORATE GOVERNANCE, PERSENTASE KEPEMILIKAN MANAJERIAL DAN FIRM SIZE TERHADAP TINGKAT PENGUNGKAPAN LAPORAN KEUANGAN
}

\author{
Deranika Ratna Kristiana \\ Sekolah Tinggi Ilmu Ekonomi \\ YKPN YOGYAKARTA \\ dera.nika@yahoo.com
}

\begin{abstract}
This research aims to examine the effect of Income Smoothing to the level of disclosure of financial reports. The implementation of good corporate governance effects to the level of disclosure of financial reports, managerial ownership effects the to the level of disclosure of financial reports and firm size effects to the level of disclosure of financial reports. The sample used in this research is the top 10 company CGPI (Corporate Governance Perception Index) in the period from 2010 to 2014. Hypotheses are test by multiple linear regression. The results show that Income Smoothing is a positive influence on the level of disclosure of financial statement. There are positive effect between good corporate governance to the level of disclosure of financial reports. There is no positive correlation between percentage of managerial ownership to the level of disclosure of financial reports and positive influence of company size and the level of disclosure of financial statements.
\end{abstract}

Keywords: financial statement disclosure, income smoothing, good corporate governance, managerial ownership, and firm size

\section{PENDAHULUAN}

Income smoothing adalah suatu fenomena yang sering terjadi dan sering dilakukan di banyak Negara. Praktik Income smoothing jika dilakukan dengan kesengajaan dapat menyebabkan pengungkapan laba yang menyesatkan perusahaan. Dalam hal ini investor tidak memperoleh informasi yang akurat dan memadai mengenai laba perusahaan untuk mengevaluasi hasil baik keuntungan ataupun risiko yang terjadi dari portofolio mereka sehingga dapat mempengaruhi motivasi investor untuk kembali berinvestasi pada perusahaan tersebut. Konsep Income Smoothing menurut Fudenberg dan Tirole (1995) dalam Mursalim (2005), mengasumsikan bahwa investor adalah orang yang menolak risiko. Laba yang dicapai perusahaan tidak stabil akan memungkinkan investor beranggapan bahwa investasi tersebut memiliki risiko tinggi, sehingga sangat mempengaruhi investor untuk memutuskan berinvestasi di perusahaan tersebut.
Hal ini dapat dikatakan bahwa laba perusahaan yang tidak normal atau tidak stabil memungkinkan investor menganggap investasi yang akan dilakukan memiliki risiko bahkan risiko yang sangat tinggi, sehingga dapat mempengaruhi motivasi investor untuk berinvestasi pada perusahaan tersebut.

Income smoothing merupakan normalisasi laba yang dilakukan dengan kesengajaan untuk mencapai suatu tren atau level tertentu (Belkaouli, 1984 dalam Kustiani dan Ekawati, 2006).

Good coorporate governance sering terjadi di Indonesia karena proses pencatatan laporan keuangan dan proses penyusunan laporan keuangan tidak sesuai dengan ketentuan yang berlaku. Dalam hal ini menyebabkan laporan keuangan pada suatu perusahaan dikatakan belum andal maka diterapkanlah Good coorporate governance berdasarkan prinsip transparansi, kemandirian, akuntabilitas, pertanggungjawaban dan kewajaran. Dengan adanya Good coorporate governance 
diharapkan terciptanya stakeholder perusahaan yang efektif bagi manajemen perusahaan agar proses pencatatan dan proses penyusunan laporan keuangan dapat dikatakan andal.

Persentase kepemilikan manajerial adalah besarnya proporsi kepemilikan saham yang dimiliki oleh pihak manajemen dalam suatu perusahaan, sehingga manajemen berhak dalam pengambilan keputusan. Struktur kepemilikan manajerial dapat diketahui dari daftar pemegang saham.

Perusahaan dengan ukuran yang lebih besar seharusnya mengungkapkan laporan keuangan yang lebih luas dibandingkan dengan ukuran perusahaan yang kecil. Ukuran perusahaan yang besar cenderung lebih banyak mengungkapkan butir-butir laporan keuangan yang lebih detail daripada perusahaan yang berukuran kecil karena mempunyai banyak informasi yang harus diungkapkan. Perusahaan kecil biasanya membutuhkan biaya tambahan untuk mengungkapkan laporan keuangan agar penyusunan laporan keuangan lengkap seperti perusahaan yang berukuran besar dengan maksud dan tujuan tertentu.

\section{Pengungkapan Laporan Keuangan}

Perusahaan dituntut oleh para investor pelanggan, ataupun pemerintah untuk memuat laporan keuangan tentang kinerja perusahaan yang telah dicapai, tentunya lebih dari sekedar menyajikan informasi kinerja keuangan. Banyak perusahaan yang memasukkan informasi baik atas kinerja keuangan ataupun kinerja non keuangan yang berkaitan dengan aspek operasional perusahaan (Waterhouse dan Spenden, 1998 dalam Prayogi, 2003). Hal penting yang harus diperhatikan dalam pengungkapan adalah untuk siapa informasi diungkap, apa tujuan informasi tersebut, dan berapa banyak informasi yang diungkap.

Konsep yang umumnya dikemukakan oleh perusahaan adalah:

1. Adequate disclosure mengandung arti pengungkapan yang minimal harus ada sehingga laporan tidak menyesatkan.

2. Fair disclosure menyatakan tujuan-tujuan etis untuk memberikan perlakuan yang sama bagi semua pembaca potensial.
3. Full disclosure berarti penyajian semua informasi yang relevan.

Luas pengungkapan laporan keuangan mencerminkan kualitas informasi yang disajikan oleh perusahaan, terutama yang berkaitan dengan kondisi keuangan perusahaan. Hal ini berarti semakin luas pengungkapan yang dilakukan oleh suatu perusahaan akan meningkatkan kualitas informasi yang mungkin akan didapat oleh pengguna laporan keuangan terutama yang berhubungan dengan kondisi keuangan suatu perusahaan.

\section{Teori Manajemen Laba Dan Perataan Laba}

Manajemen banyak memanfaatkan standar pelaporan keuangan dengan cara menerapkan standar yang dipercepat pengadobsiannya. Selain itu standar juga dijadikan sebagai alat untuk melaporkan kondisi perusahaan. Fleksibilitas yang terdapat dalam standar akuntansi pada akhirnya menyebabkan tindakan tersebut sah dengan sendirinya. Sedangkan kecurangan dalam pelaporan keuangan lebih merupakan upaya manajemen untuk menyembunyikan atau memanipulasi sebagian atau seluruh informasi keuangan dengan cara-cara yang tidak sesuai dengan standar akuntansi yang berlaku.

Khafid (2004:43) menyatakan pemilik mendukung perataan laba karena adanya motivasi internal dan motivasi eksternal. Motivasi internal menunjukkan maksud pemilik untuk meminimalisasi biaya kontrak manajer dengan membujuk manajer agar melakukan praktik manajemen laba. Motivasi eksternal ditujukan oleh usaha pemilik saat ini untuk mengubah persepsi prospektif investor atau potensial terhadap nilai perusahaan. Menurut Belkaoui (2007:194) tiga batasan yang mungkin mempengaruhi para manajer untuk melakukan perataan laba adalah:

1. Mekanisme pasar yang kompetitif sehingga mengurangi jumlah pilihan yang tersedia bagi manajemen.

2. Skema kompensasi manajemen yang terhubung langsung dengan kinerja perusahaan.

3. Ancaman penggantian manajemen. 
Menurut Koch (1981) dalam Mursalim (2003:162) tindakan perataan laba dapat didefinisikan sebagai suatu sarana yang digunakan manajemen untuk mengurangi variabilitas urut-urutan, pelaporan laba relatif terhadap beberapa urut-urutan target yang terlihat karena adanya manipulasi variabelvariabel akuntansi semu (artificial smoothing) atau transaksi riil (real smoothing). Perataan laba merupakan normalisasi laba yang dilakukan secara sengaja untuk mencapai trend atau tingkat yang diinginkan. Perataan laba sebagai proses manipulasi profit waktu earning atau pelaporan earning agar aliran laba yang dilaporkan perubahannya lebih sedikit.

Asimetri informasi yang terjadi antara manajer dengan pemegang saham sebagai pengguna laporan keuangan menyebabkan pemegang saham tidak dapat mengamati seluruh kinerja dan prospek perusahaan secara sempurna. Dalam situasi dimana pemegang saham memiliki informasi yang lebih sedikit dari manajer, manajer dapat memanfaatkan fleksibilitas yang dimilikinya untuk melakukan manajemen laba.

Manajemen laba berpengaruh signifikan positif pada tingkat pengungkapan laporan keuangan sejalan dengan perspektif efficient earnings management. Akan tetapi, tingkat pengungkapan berpengaruh signifikan negatif pada manajemen laba sejalan dengan perspektif opportunistic earnings management.

$\mathrm{H} 1$ : Income smoothing berpengaruh positif terhadap pengungkapan laporan keuangan

\section{Good Corporate Governance (Tata Kelola Perusahaan)}

Sebagaimana yang diuraikan oleh OECD (Organization for Economic Cooperation and Development), ada empat unsur penting dalam corporate governance, yaitu:

1. Fairness (keadilan): Menjamin perlindungan hak-hak para pemegang saham, termasuk hak-hak pemegang saham minoritas dan para pemegang saham asing, serta menjamin terlaksananya komitmen dengan para investor.
2. Transparency (transparansi): Mewajibkan adanya suatu informasi yang terbuka, tepat waktu, serta jelas, dan dapat diperbandingkan yang menyangkut keadaan keuangan, pengelolaan perusahaan, dan kepemilikan perusahaan.

3. Accountability (akuntabilitas): Menjelaskan peran dan tanggung jawab, serta mendukung usaha untuk menjamin penyeimbangan kepentingan manajemen dan pemegang saham, sebagaimana yang diawasi oleh dewan komisaris.

4. Responsibility (pertanggungjawaban): Memastikan dipatuhinya peraturan serta ketentuan yang berlaku sebagai cerminan dipatuhinya nilai-nilai sosial. $(O E C D$ Business Sector Advisory Group on Corporate governance, 1998.

Perusahaan-perusahaan yang melaksanakan good corporate governance akan memberikan lebih banyak informasi dalam rangka mengurangi asimetri informasi. Informasi yang diberikan akan ditunjukkan dalam tingkat pengungkapan, semakin baik pelaksanaan good corporate governance oleh suatu perusahaan, maka akan semakin banyak informasi yang diungkap.

H2: Good corporate governance berpengaruh positif terhadap pengungkapan laporan keuangan

\section{Persentase Kepemilikan Manajerial}

Persentase kepemilikan manajerial merupakan presentase atau proporsi saham yang dimiliki oleh manajemen (Faizal, 2004). Sedangkan kepemilikan manajemen adalah pemegang saham yang dari pihak manajemen yang secara aktif ikut dalam pengambilan keputusan perusahaan (Direktur dan komisaris). Persentase kepemilikan manajerial dapat diketahui dari daftar pemegang saham. Menurut Sujoko dan Soebiantoro (2007), kepemilikan manajerial merupakan kepemilikan saham oleh manajemen perusahaan yang diukur dengan persentase jumlah saham yang dimiliki oleh manajemen (Sujoko dan Soebiantoro, 2007). kepemilikan manajerial dapat didefinisikan sebagai persentase, proporsi atau besarnya proporsi kepemilikan saham yang dimiliki oleh 
pihak manajemen (misal: direktur dan komisaris) dalam suatu perusahaan, dimana manajemen juga turut ambil bagian dalam pengambilan keputusan dalam perusahaan

Ross et al., (2008), menyatakan bahwa semakin besar persentase kepemilikan saham dalam suatu perusahaan maka manajemen cenderung lebih aktif untuk kepentingan pemegang saham yang tidak lain adalah dirinya sendiri. Kepemilikan saham manajerial akan membantu penyatuan kepentingan antara manajer dan pemegang saham, sehingga manajer ikut merasakan secara langsung manfaat dari keputusan yang diambil dan ikut pula menanggung kerugian sebagai konsekuensi dari pengambilan keputusan yang salah.

Kepemilikan manajerial menyebabkan berkurangnya tindakan oportunis manajer untuk memaksimalkan kepentingan pribadi. Manajer perusahaan akan mengambil keputusan sesuai dengan kepentingan perusahaan, yaitu dengan cara mengungkapkan informasi sosial yang seluas-luasnya untuk meningkatkan image perusahaan meskipun ia harus mengorbankan sumber daya untuk aktivitas tersebut (Anggraini, 2006).

Manajer yang memiliki saham perusahaan tentunya akan menyelaraskan kepentingannya sebagai manajer dengan kepentingannya sebagai pemegang saham. Semakin besar persentase kepemilikan manajerial dalam perusahaan maka semakin produktif tindakan manajer dalam memaksimalkan nilai perusahaan.

\section{H3: Persentase kepemilikan manajerial berpengaruh positif terhadap pengungkapan laporan keuangan.}

\section{Firm Size}

Ukuran (size) perusahaan dapat dinyatakan dalam total aset, penjualan dan kapitalisasi pasar. Semakin besar total aset, penjualan dan kapitalisasi pasar maka semakin besar pula ukuran perusahaan tersebut. Ketiga variabel ini digunakan untuk menentukan ukuran perusahaan karena dapat mewakili seberapa besar perusahan tersebut.

Ukuran perusahaan dapat mempengaruhi kelengkapan pengungkapan laporan keuangannya. Perusahaan yang berukuran besar cenderung lebih banyak mengungkapkan butirbutir laporan keuangannya karena mereka memiliki lebih banyak informasi yang dapat diungkapkan (Wallace et al.,1994).

H4: Ukuran perusahaan berpengaruh positif tingkat pengungkapan laporan keuangan

\section{RERANGKA PIKIR}

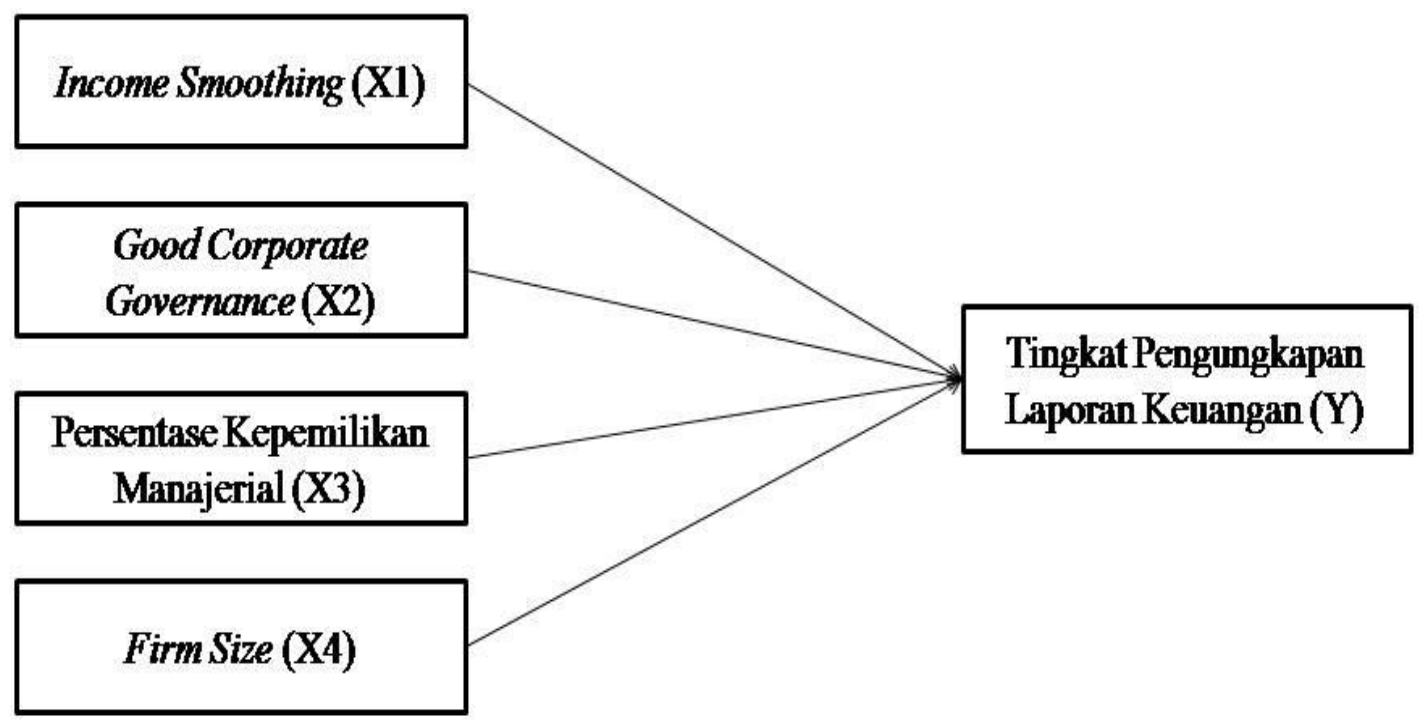




\section{METODOLOGI PENELITIAN}

Objek penelitian yang digunakan dalam penelitian ini adalah semua perusahaan publik yang terdaftar di Bursa Efek Indonesia (BEI). Sampel dipilih dengan purposive random sampling method. Penelitian ini menggunakan data sekunder yaitu laporan tahunan dan laporan keuangan. Data penelitian mencakup data tahun 2010 - 2014 yang dipandang cukup mewakili kondisi untuk analisis.

Tabel 1

Variabel Penelitian

\begin{tabular}{|c|c|c|c|c|}
\hline No. & Variabel & Konsep Variabel & Indikator & Skala \\
\hline 1. & $\begin{array}{l}\text { Tingkat } \\
\text { pengungkapan } \\
\text { laporan keuangan } \\
\text { (IP) }\end{array}$ & $\begin{array}{l}\text { Indeks pengungkapan } \\
\text { yang diterbitkan } \\
\text { perusahaan } \\
\text { dibandingkan dengan } \\
\text { indeks pengungkapan } \\
\text { sukarela }\end{array}$ & $\begin{array}{l}\text { Item pengungkapan } \\
\text { sukarela dalam } \\
\text { laporan tahunan } \\
\text { perusahaan }\end{array}$ & Rasio \\
\hline 2. & $\begin{array}{l}\text { Income } \\
\text { smoothing (IS) }\end{array}$ & $\begin{array}{l}\text { Pengelompokan } \\
\text { perusahaan sebagai } \\
\text { perata laba atau bukan } \\
\text { perata laba }\end{array}$ & $\begin{array}{l}\text { Dummy: } \\
1=\text { Melakukan IS } \\
0=\text { Tidak } \\
\text { melakukan IS }\end{array}$ & Skala \\
\hline 3. & $\begin{array}{l}\text { Good corporate } \\
\text { governance } \\
\text { (GCG) }\end{array}$ & $\begin{array}{l}\text { Penerapan corporate } \\
\text { governance pada } \\
\text { perusahaan }\end{array}$ & $\begin{array}{l}\text { Corporate } \\
\text { governance } \\
\text { perception index } \\
\text { (CGPI) }\end{array}$ & Rasio \\
\hline 4. & $\begin{array}{l}\text { Persentase } \\
\text { kepemilikan } \\
\text { manajerial (KM) }\end{array}$ & $\begin{array}{l}\text { Persentase besarnya } \\
\text { saham yang dimiliki } \\
\text { oleh pihak manajemen } \\
\text { dibandingkan dengan } \\
\text { jumlah saham secara } \\
\text { keseluruhan }\end{array}$ & $\begin{array}{l}\text { Jumlah saham } \\
\text { pihak manajemen }\end{array}$ & Rasio \\
\hline 5. & Firm size (SIZE) & $\begin{array}{l}\text { Ukuran perusahaan } \\
\text { dinyatakan dalam total } \\
\text { aset yang dimiliki } \\
\text { perusahaan. }\end{array}$ & Ln (total aset) & Rasio \\
\hline
\end{tabular}

Metode Analisis Data

Teknik analisis data yang digunakan dalam penelitian ini adalah moderated regression analysis (MRA). Model persamaan regresi penelitian adalah sebagai berikut:

$$
\begin{aligned}
\mathrm{IPt}= & \beta 0+\beta 1 \mathrm{ISt}+\beta 2 \mathrm{GCGt}+\beta 3 \mathrm{KMt}+\beta 4 \\
& \mathrm{SIZE}+\varepsilon
\end{aligned}
$$

Ist

GCGt : Good corporate governance pada tahun $\mathrm{t}$ yang diukur dengan Corporate Perception Index (CGPI)

KMt : Persentase kepemilikan manajerial yang akan diukur dengan prosentase kepemilikan saham oleh pihak manajemen

SIZEt $\quad: \quad$ Log natural total aset

$\varepsilon \quad$ : Error term 


\section{HASIL DAN PEMBAHASAN}

Nilai rata-rata luas pengungkapan sukarela (IP) adalah sebesar 0,59 yang menunjukkan bahwa secara rata-rata perusahaan yang diteliti selama tahun 2010-2014 tidak mengungkapkan secara menyeluruh. Incoming smoothing mempunyai rata-rata sebesar 0,283. Rata-rata good corporate governance (GCG) sebesar
0,847 yang menunjukkan kecenderungan perusahaan 10 besar CGPI telah memenuhi ketentuan peraturan di Indonesia. Persentase kepemilikan manajerial (KM) 0,003 dimana kepemilikan saham yang dimiliki oleh pihak manajemen sangat kecil. Rata-rata total aset perusahaan sebesar 31,701 yang merupakan nilai hasil $\ln$ aset total.

Tabel 2

Statistik Deskriptif Variabel Penelitian

\begin{tabular}{llrrrr}
\hline \multicolumn{1}{c}{ Variabel } & N & Minimum & Maximum & Mean & $\begin{array}{c}\text { Std. } \\
\text { Deviation }\end{array}$ \\
\hline IP_t & 60 & 0,261 & 0,652 & 0,459 & 0,115 \\
IS_t & 60 & 0,000 & 1,000 & 0,283 & 0,454 \\
GCG_t & 60 & 76,454 & 91,919 & 84,697 & 47,687 \\
KM_t & 60 & 0,000 & 0,160 & 0,003 & 0,021 \\
SIZE_t & 60 & 25,907 & 34,382 & 31,701 & 1,802 \\
\hline
\end{tabular}

Sumber: Olah data

Suatu model regresi akan memberikan hasil berupa nilai parameter yang valid atau dapat menjadi pemprediksi yang baik apabila dapat memenuhi asumsi klasik. Model yang digunakan untuk pengujian asumsi klasik yaitu uji normalitas, uji multikolinearitas, uji autokorelasi dan uji heteroskedasitas.

Uji normalitas diperlukan untuk mengetahui pola distribusi data yang digunakan dan dengan mengetahui pola distribusi data yang digunakan dalam penelitian, maka peneliti dapat menentukan uji statistik yang tepat dalam rangka melakukan pengujian hipotesis penelitian. Uji normalitas dalam penelitian ini menggunakan nilai Kolmogorov-Smirnov (KS). Apabila nilai KS mempunyai tingkat signifikansi lebih besar daripada tingkat signifikansi 0,05 atau 5\%, maka dapat disimpulkan bahwa data berdistribusi normal.

Uji multikolinearitas adalah uji yang digunakan untuk mengetahui ada tidaknya suatu hubungan linear yang sempurna atau mendekati sempurna antara beberapa atau semua variabel independen. Salah satu deteksi ada tidaknya multikolinearitas adalah dengan melihat pada nilai Variance Inflation Factor (VIF). Nilai batas yang umum dipakai adalah nilai tolerance 0,1 atau VIF 10 (Hair et. al. 1998). Jika VIF dari suatu variabel melebihi 10 maka terjadi multikolinearitas hal ini terjadi ketika nilai $\mathrm{R}^{2}$ melebihi 0,90 . Model yang baik adalah model yang terbebas dari masalah multikoliniearitas.

Autokorelasi terjadi apabila gangguan dalam periode tertentu berhubungan dengan nilai gangguan periode sebelumnya. Masalah autokorelasi muncul karena observasi yang berurutan sepanjang waktu berkaitan satu dengan lainnya. Pengujian autokorelasi dapat dilakukan dengan uji Durbin Watson. Model dikatakan mengalami masalah autokorelasi jika nilai DW di luar kisaran nilai antara 1,864 2,136 .

Heteroskedastisitas adalah suatu keadaan dimana masing-masing kesalahan pengganggu mempunyai varian yang berlainan. Heteroskedastisitas diuji dengan menggunakan uji koefisien korelasi Rank Spearman yaitu mengkorelasikan antara absolut residual hasil regresi dengan semua variabel bebas. Bila signifikansi hasil korelasi lebih kecil dari 0,05 maka persamaan regresi tersebut mengandung heteroskedastisitas dan sebaliknya berarti non 
heteroskedastisitas atau homoskedastisitas. mengkorelasikan antara absolut residual hasil Heteroskedastisitas diuji dengan menggunakan regresi dengan semua variabel bebas. uji koefisien korelasi Rank Spearman yaitu

Tabel 3

Hasil Uji Asumsi Klasik

\begin{tabular}{llll}
\hline \multicolumn{1}{c}{ Uji Asumsi Klasik } & \multicolumn{2}{c}{ Hasil } & Kesimpulan \\
\hline Uji Normalitas & $\begin{array}{l}\text { Residual tidak } \\
\text { standardisasi: }\end{array}$ & ter- & Data normal \\
Kolmogorov-smirnov $Z$ & & 0,090 & \\
Asymp. Sig (2-tailed) & & 0,200 & \\
Uji Multikolinearitas & VIF & & \\
IS_t & & 1,137 & Bebas multikolinearitas \\
GCG_t & & 1,177 & Bebas multikolinearitas \\
KM_t & 1,141 & Bebas multikolinearitas \\
SIZE_t & & 1,257 & Bebas multikolinearitas
\end{tabular}

Uji Autokorelasi

Durbin-Watson

Uji Heteroskedastisitas

IS_t

GCG_t

KM_t

SIZE_t
Sig.

\section{0,600 Ada autokorelasi}

$\begin{array}{ll}0,788 & \text { Bebas heteroskedastisitas } \\ 0,773 & \text { Bebas heteroskedastisitas } \\ 0,162 & \text { Bebas heteroskedastisitas } \\ 0,705 & \text { Bebas heteroskedastisitas }\end{array}$

Pengujian hipotesis dalam penelitian menggunakan analisis regresi berganda. Analisis regresi berganda ini dilakukan dengan meregresikan variabel dependen yang diwakili oleh IP dengan variabel independen yang diwakili oleh IS, GCG, KM dan SIZE. Tabel berikut menunjukkan rangkuman hasil pengujian regresi yang telah dilakukan.

Tabel 4

Hasil Uji Regresi

\begin{tabular}{lrrr}
\hline \multirow{2}{*}{ Variabel } & \multicolumn{2}{c}{$\begin{array}{l}\text { Koefisien tidak } \\
\text { terstandarisasi }\end{array}$} & $\begin{array}{c}\text { Koefisien } \\
\text { terstandarisasi }\end{array}$ \\
\cline { 2 - 4 } & \multicolumn{1}{c}{ B } & Std. Error & \multicolumn{1}{c}{ Beta } \\
\hline (Constant) & $-0,376$ & 0,311 & \\
IS_t & 0,021 & 0,033 & 0,083 \\
GCG_t & 0,930 & 0,317 & 0,386 \\
KM_t & $-0,736$ & 0,715 & $-0,133$ \\
SIZE_t & 0,001 & 0,009 & 0,022 \\
\hline
\end{tabular}

Sumber: Olah data

Berdasarkan hasil analisis regresi tersebut, maka diperoleh persamaan regresi sebagai berikut:

$$
\begin{aligned}
\mathrm{IPt}= & -0,376+0,021 \mathrm{ISt}+0,930 \mathrm{GCGt} \\
& -0,736 \mathrm{KMt}+0,001 \mathrm{SIZE}
\end{aligned}
$$

Pada penelitian ini hanya terdapat 17 perusahaan yang termasuk perata laba dan 43 perusahaan yang bukan perata laba. Sebagian besar perusahaan yang digunakan untuk sampel penelitian tidak dapat menghasilkan laba besar 
dibandingkan dengan penjualannya. Meskipun bukan sebagai perata laba namun lebih berdasarakn kepada transparansi maka perusahaan akan mengungkapkan item-item laporan keuanagn secara detail sehingga luas pengungkapan akan semakin banyak. Pelaksanaan GCG menggunakan proksi corporate governance perception index (CGPI) yang merupakan hasil pemeringkatan penerapan corporate governance yang dilaporkan oleh the indonesian institute for corporate governance (IICG). Peneltiian ini menggunakan sampel perusahaan yang termasuk 10 besar CGPI sehingga nilai GCG juga besar yaitu berada pada kisaran $76,45 \%$ sampai $91,91 \%$ dengan rata-rata $84,69 \%$. Perusahaan BUMN atau perusahaan milik publik dituntut untuk tranparan sehingga butir-butir laporan keuangan yang diungkapkan semakin banyak. Penolakan hipotesis mengenai persentase kepemilikan manajerial tersebut dikarenakan banyak perusahaan yang tidak atau hanya memiliki kepemilikan manajerial di bawah 5\% sehingga dengan kepemilikan yang relatif sedikit tersebut tidak dapat menjadi faktor pendorong manajemen untuk melakukan melakukan pengungkapan sukarela karena manajemen tidak merasa memiliki perusahaan. IP sebagai tingkat pengungkapan sukarela diperoleh dengan mengidentifikasi item pengungkapan sukarela dalam laporan tahunan perusahaan. Semakin banyak item pengungkapan sukarela yang disertakan dalam laporan tahunan, maka akan semakin besar indeks pengungkapan sukarela perusahaan. Hasil penelitian ini mendukung Wallace et al. (1994) dimana perusahaan yang berukuran besar cenderung lebih banyak mengungkapkan butir-butir laporan keuangannya karena mereka memiliki lebih banyak informasi yang dapat diungkapkan.

Tabel 5

Hasil Uji Hipotesis

\begin{tabular}{lcccc}
\multicolumn{1}{c}{ Hipotesis } & Variabel & $\begin{array}{c}\text { t } \\
\text { hitung }\end{array}$ & Sig & Kesimpulan \\
\hline $\begin{array}{l}\text { H1: Income smoothing } \\
\text { berpengaruh positif terhadap } \\
\text { tingkat pengungkapan laporan } \\
\text { keuangan }\end{array}$ & IS_t & 0,639 & 0,525 & Diterima \\
$\begin{array}{l}\text { H2: Good corporate } \\
\text { governance berpengaruh positif } \\
\text { terhadap tingkat pengungkapan } \\
\text { laporan keuangan }\end{array}$ & GCG_t & 2,932 & 0,005 & Diterima \\
$\begin{array}{l}\text { H3: Persentase kepemilikan } \\
\text { manajerial berpengaruh positif } \\
\text { terhadap tingkat pengungkapan }\end{array}$ & & & & \\
laporan keuangan & KM_t & $-1,029$ & 0,308 & Ditolak \\
$\begin{array}{l}\text { H4: Ukuran perusahaan } \\
\text { berpengaruh positif terhadap } \\
\text { tingkat pengungkapan laporan } \\
\text { keuangan }\end{array}$ & & & & \\
\hline
\end{tabular}




\section{KESIMPULAN}

Penelitian ini mempunyai tujuan untuk menguji pengaruh Income Smoothing, Good Corporate Governance dan kepemilikan manajerial terhadap tingkat pengungkapan laporan keuangan. Income Smoothing berpengaruh positif terhadap tingkat pengungkapan laporan keuangan. Tidak terdapat pengaruh negatif antara good corporate governance dengan tingkat pengungkapan laporan keuangan. Tidak terdapat pengaruh positif antara Persentase Kepemilikan Manajerial terhadap tingkat pengungkapan laporan keuangan. Ukuran perusahaan berpengaruh positif terhadap tingkat pengungkapan laporan keuangan.

\section{Saran}

Penelitian selanjutnya sebaiknya Menggunakan sampel perusahaaan yang mempunyai karakteristik sejenis seperti perusahaan manufaktur, perbankan atau lainnya, (2) Menambahkan variabel baru yang mungkin dapat mempengaruhi pengungkapan laporan keuangan., (3) Memilih alat ukur yang lebih searah sehingga akan mengurangi salah interpretasi.

\section{Keterbatasan Penelitian}

Keterbatasan dalam penelitian ini yaitu (1) Penggunaan tingkat pengungkapan laporan keuangan dapat menyebabkan salah interpretasi apabila tidak dilakukan secara hati-hati, (2) Banyak informasi kepemilikan manajerial yang tidak terungkap secara baik. Hal ini menyebabkan kesulitan untuk menentukan perusahaan dengan kepemilikan manajerial atau tidak.

\section{DAFTAR PUSTAKA}

Antariksa B dan Eka A, 2005, Faktor-Faktor yang Mempengaruhi Praktik Perataan Laba Pada Perusahaan-Perusahaan Di Bursa Efek Jakarta, Jurnal Akuntansi \& Investasi, Vol. 6, No. 2.

Baridwan, Zaki, 2004, Intermediate Accounting, Edisi Delapan, BPFE, Yogyakarta.

Beidleman, C., 1973, Income Smoothing: The Role of Management, The Accounting Review, (October), p. 653-668
Deasi K dan Erni E, 2006, Analisis Perataan Laba dan Faktor-Faktor yang Mempengaruhi: Studi Empiris Pada Perusahaan Di Indonesia, Jurnal Riset Akuntansi dan Keuangan, Vol. 2, No. 1.

Edy $\mathrm{S}$ dan Arleen $\mathrm{H}$, Analisis Pengaruh Karakteristik Perusahaan Terhadap Tindakan Perataan Laba yang Dilakukan oleh Perusahaan yang Terdaftar Di Bursa Efek Jakarta, SNA VIII, September 2005.

Faizal. 2004. Analisis Agency Costs, Struktur Kepemilikan dan Mekanisme Corporate Governance. Simposium Nasional Akuntansi VII. DenpasarBali, 2-3 Desember.

FCGI, 2000. Corporate Governance (Tata kelola Perusahaan). Booklet Jilid I Edisi ke-1.

FCGI, 2000. Peranan Dewan Komisaris dan Komite Audit dalam Pelaksanaan Corporate Governance (Tata kelola Perusahaan). Booklet Jilid II Edisi ke-2

Fudenberg D dan Tirole J. 1995. A Theory of income and dividend smoothing based on incumbency rent. Journal of political economy 103, 75-93

Hadri Kusuma \& Wigiya Ayu Udiana Sari, 2003, Manajemen Laba Oleh Perusahaan Pengakuisisi Sebelum Merger dan Akuisisi Di Indonesia, JAAI Volume 7 No. 1, Juni 2003

Harry Prihatmoko, Wibowo, dan Murtanto, 2004, Analisis Perataan Laba (Income Smoothing): Faktor-faktor yang Mempengaruhi dan Kaitannya dengan Kinerja Saham Perusahaan Publik di Indonesia, Media Riset Akuntansi, Auditing \& Informasi, Vol. 4, No. 3.

Iturriaga, F.J.L. dan Sanz, J.A.R. 2000. Ownership Structure, Corporate Value and Firm Investment: A Spanish Firms Simultaneous Equation Analysis. 
Working Paper Universidad de Valladolid, 1-32

Januar E, Sri Astuti, dan Agung W, 2002, Praktik Perataan Laba dan Kinerja Saham Perusahaan Publik Di Indonesia, JAAI, Vol. 6, No. 2.

Jatiningrum, 2000, Analisis Faktor-Faktor yang Berpengaruh Terhadap Perataan Penghasilan Bersih/ Laba Pada Perusahaan yang Terdaftar di BEJ, Jurnal Bisnis dan Akuntansi, Vol 2, No. 2.

Jogiyanto, 2003, Teori Portofolio dan Analisis Investasi, Edisi 3. BPFE UGM, Yogyakarta.

Juniarti, Corolina, 2005, Analisis Faktor-faktor yang Berpengaruh terhadap Perataan Laba (Income Smoothing) pada perusahaan-perusahaan Go Public, Jurnal Akuntansi dan Keuangan No 7 Vol 7, No 2 (2005): November 2005

Kustiani, D. dan E. Ekawati. 2006, Analisis Perataan Laba dan Faktor-Faktor yang mempengaruhi: Studi Empiris pada Perusahaan di Indonesia. Jurnal Riset Akuntansi dan Keuangan, Vol. 2 No. 1, Februari, hal: 53-56.

Mehran, Hamid (1992). Executive Incentive Plans, Corporate Control and Capital
Structure, Journal of Financial and Quantitative Analysis, 27, 539-560

Mursalim, 2005. Income Smoothing dan Motivasi Investor: Studi Empiris Pada Investor Di BEJ, SNA VIII, September 2005

Ross, Westerfield and Jordan, 2008, Fundamentals of Corporate Finance 9th Edition McGraw-Hill

Subekti Imam, 2005. Asosiasi Antara Praktik Perataan Laba dan Reaksi Pasar Modal Di Indonesia, SNA VIII, September 2005.

Sujoko dan Soebiantoro, U., 2007. Pengaruh Struktur Kepemilikan Saham, Leverage, Faktor Intern dan Faktor Ekstern terhadap Nilai Perusahaan, Jurnal Manajemen dan Kewirausahaan, Vol 9, 47.

Tri Gunarsih, 2003, Struktur Kepemilikan Sebagai Salah Satu Mekanisme Corporate Governance, KOMPAK, No. 08 Mei - Agustus 2003

Zulfa dan Maya, 2007, Analisis Perataan Laba (Income Smoothing): Faktor yang mempengaruhinya dan Pengaruhnya Terhadap Return dan Resiko Saham Perusahaan Go Public Di Bursa Efek Jakarta, BENEFIT, Vol. 11, No. 1. 